articular pressure will result, which will suck in the subcutaneous tissue overlying the tear and therefore also the skin. The sucked in skin is released as soon as the talus resumes its normal position, since this restores the volume, and subsequently the intra-articular pressure, to normal.

The dimple does not appear on inversion stress, because the subcutaneous tissues and skin became stretched across the joint line, whereas with posteroanterior stress the tension in the region of the anterolateral joint line is reduced.

Discussion. The anterior drawer sign is a well-known sign of ankle instability following a tear of the lateral ligament (Lindstrand 1976). The dimple sign depends on the fact that, with such a tear, invariably the joint capsule also is torn. In certain patients the sign can be produced in the emergency room though it is difficult to repeat the test without anaesthesia because of pain and protective spasm. However, its demonstration when tested only once has enabled us to predict the likelihood of rupture and to advise treatment accordingly.
The dimple has also enabled us to place the incision correctly even when swelling obscures the bony landmarks, and to limit the size of the incision because, if this is made directly over the dimple it leads straight to the tear. The sign is likely to be negative when examination under anaesthesia is delayed for seven days or more, since organised haematoma and fibrous tissue block the communication between the joint and the subcutaneous tissues; this was the case with those seven of our 50 patients in whom the sign was negative despite radiological and surgical evidence of rupture.

\section{REFERENCES}

Broström L III. Sprained ankles: clinical observations in recent ligament ruptures. Acta Chir Scand 1965:130:560-9.

Evans GA, Hardcastle P, Frenyo AD. Acute rupture of lateral ligament of the ankle: to suture or not to suture? J Bone Joint Surg [Br] 1984;66-B:209-12.

Hughes JR. Sprains and subluxations of ankle-joint. Proc $R$ Soc Med 1942;35:765-6.

Lindstrand A. New aspect in the diagnosis of lateral ankle sprain. Orthop Clin North Am 1976;7(1):247-9.

\title{
SURGICAL APPROACHES TO THE DORSUM OF THE WRIST: BRIEF REPORT
}

\author{
HAMISH POTTS, JONATHAN NOBLE
}

The surgical approach to the dorsum of the wrist, described in textbooks as "standard", may be through a transverse, lazy $\mathbf{S}$ or curved longitudinal incision. A significant number of such wounds produces complications, mainly ischaemic in nature, ranging from delayed wound healing to full thickness skin necrosis with sloughing and even tendon rupture. This is not surprising because most patients undergoing wrist surgery have rheumatoid arthritis. Our study was to determine whether straight incisions on the dorsum of the wrist resulted in fewer complications than the "standard" approaches.

Patients and results. Patients undergoing dorsal wrist surgery during a six-year period were studied; 93 wrists were operated on, mostly in patients with rheumatoid arthritis. Complications related to the incision and thus included in our results were: delayed wound healing (more than three weeks to epithelialise fully) with or without skin loss, wound infection, haematoma forma-

H. Potts, FRCS, Registrar in Orthopaedic Surgery

Salford Health Authority.

J. Noble, ChM, FRCS Ed, Consultant Orthopaedic Surgeon Hope Hospital, University of Manchester Medical School, Eccles Old Road, Salford, Lancashire M6 8HD, England.

Correspondence to $\mathrm{Mr} \mathrm{J}$. Noble.

(C) 1988 British Editorial Society of Bone and Joint Surgery

$0301-620 X / 88 / 2$ R54 $\$ 2.00$

J Bone Joint Surg [Br] 1988;70-B:328-9. tion and tendon adhesion. Also sought were sympathetic dystrophy, carpal tunnel syndrome and tendon rupture. Our results were compared with other reported series of wrist operations (Tables I and II).

The complication rate in our series, using straight incisions, was 6\% (6 cases in 93 wrists): five had delayed wound healing (none required grafting) and one had tendon adherence to skin which did not require further surgery. Nine patients underwent a second operation through the same incision, of whom three had a third or subsequent procedure by the same approach.

Table I. Wound complications in operations employing standard dorsal wrist incisions

\begin{tabular}{lccc}
\hline Author & $\begin{array}{l}\text { Number of } \\
\text { wrists }\end{array}$ & $\begin{array}{l}\text { Number of } \\
\text { complications }\end{array}$ & Per cent \\
\hline Carroll and Dick 1971 & 27 & 0 & 0 \\
Millender and Nalebuff 1973 & 70 & 4 & 6 \\
Lichtman et al. 1977 & 20 & 2 & 10 \\
Millender et al. 1974 & 93 & 11 & 12 \\
Abernethy and Dennyson 1979 & 14 & 2 & 14 \\
Papaiannou and Dickson 1982 & 12 & 4 & 33 \\
Rana and Taylor 1973 & 9 & 9 & 100 \\
Noble 1987 & 19 & 4 & 21 \\
Total & 264 & 36 & 13 \\
\hline
\end{tabular}


Table II. Wound complications in operations employing straight dorsal wrist incision

\begin{tabular}{lccc}
\hline Author & $\begin{array}{l}\text { Number of } \\
\text { wrists }\end{array}$ & $\begin{array}{l}\text { Number of } \\
\text { complications }\end{array}$ & Per cent \\
\hline Swanson 1973 & 15 & 0 & 0 \\
Rana and Taylor 1973 & 77 & 0 & 0 \\
Mikkelson 1980 & 59 & 0 & 0 \\
Abernethy and Dennyson 1979 & 40 & 2 & 5 \\
Meuli 1980 & 41 & 2 & 5 \\
Mannerfelt and Malmstein 1971 & 43 & 4 & 10 \\
Noble 1987 & 93 & 6 & 6 \\
Total & 368 & 14 & 3 \\
\hline
\end{tabular}

When a "standard" incision was used our complication rate was higher, $21 \%$ ( 4 cases in 19 wrists); three patients had delayed healing and one had secondary haemorrhage requiring further surgery.

Discussion. The most striking feature in Table $I$ is the wide variation in quoted complication rates. Perhaps one man's delayed healing is not another's. What seems clear however is the lower incidence of wound complications when a straight incision is used. The extent of surgery performed had little bearing on wound problems; some minor surgery produced high complication rates (Rana and Taylor 1973), while more extensive procedures produced none (Carroll and Dick 1971).

All surgical incisions are designed primarily to give "adequate accurate access"; in no instance did a straight incision prove inadequate in this respect. Straight incisions are re-usable, a considerable advantage in the rheumatoid patient who may eventually need several wrist operations. Moreover, the scars produced by straight dorsal incisions never formed contractures and the cosmetic results were invariably good. For these reasons, and because they have no disadvantages we strongly recommend the use of straight incisions on the dorsum of the wrist.

\section{REFERENCES}

Abernethy PJ, Dennyson WG. Decompression of the extensor tendons at the wrist in rheumatoid arthritis. J Bone Joint Surg [Br] 1979;61-B:64-8.

Carroll RE, Dick HM. Arthrodesis of the wrist for rheumatoid arthritis. J Bone Joint Surg [Am] 1971:53-A :1365-9.

Lichtman DM, Mack GR, MacDonald R, Gunther SF, Wilson JN. Kienböck's disease: the role of silicone replacement arthroplasty. J Bone Joint Surg [Am] 1977;59-A :899-908.

Mannerfelt L, Malmstein M. Arthrodesis of the wrist in rheumatoid arthritis. Scand J Plast Reconstr Surg 1971:5:124-30.

Meuli HC. Arthroplasty of the wrist. Clin Orthop 1980:149:118-25.

Mikkelsen OA. Arthrodesis of the wrist in rheumatoid arthritis. Hand 1980;12:149-53.

Millender LH, Nalebuff EA. Arthrodesis of the rheumatoid wrist : an evaluation of sixty patients and a description of a different surgical technique. J Bone Joint Surg [Am] 1973:55-A :1026-34.

Millender LH, Nalebuff EA, Albin R, Ream JR, Gordon M. Dorsal tenosynovectomy and tendon transfer in the rheumatoid hand. $J$ Bone Joint Surg [Am] 1974;56-A :601-10.

Papaioannou T, Dickson RA. Arthrodesis of the wrist in rheumatoid arthritis. Hand 1982;14:12-6.

Rana NA, Taylor AR. Excision of the distal end of the ulna in rheumatoid arthritis. J Bone Joint Surg [Br] 1973:55-B:96-105.

Swanson AB. Flexible implant arthroplasty for arthritic disabilities of the radiocarpal joint: a silicon rubber intramedullary stemmed flexible hinge implant for the wrist joint. Orthop Clin North Am 1973;4:383-94.

\title{
SCIATIC PALSY FOLLOWING REDUCTION OF A DISLOCATED PROSTHESIS: BRIEF REPORT
}

\author{
I. STOCKLEY, D. BICKERSTAFF
}

Case report. A 74-year-old lady underwent a left exchange hip arthroplasty for aseptic loosening. Fourteen years previously, she had had a left Müller total hip replacement for osteoarthritis. At the second operation the hip was exposed using a trochanteric osteotomy and a complete capsulectomy was performed, the sciatic nerve being identified and protected throughout. Immediately

I. Stockley, FRCS, Sir Harry Platt Research Fellow

Department of Orthopaedics, Hope Hospital, Eccles Old Road, Salford, Lancashire M6 8HD, England.

D. Bickerstaff, FRCS, FRCS Ed, Orthopaedic Registrar

King Edward VII Orthopaedic Hospital, Rivelin Valley Road, Sheffield, S6 5SU, England.

Correspondence to $\mathrm{Mr}$ I. Stockley.

(C) 1988 British Editorial Society of Bone and Joint Surgery $0301-620 \mathrm{X} / 88 / 2 \mathrm{R} 48 \$ 2.00$

J Bone Joint Surg [Br] 1988;70-B:329-30. after the operation there was no evidence of a sciatic nerve palsy, but 18 hours later the patient complained of severe pain in the left hip after being turned. The radiograph showed a posterior dislocation of the femoral prosthesis.

A closed reduction was performed but, on recovering from the anaesthetic, the patient complained of pain down the back of the left leg from buttock to toes. She had patchy loss of sensation in the lower leg and a total sciatic motor palsy. The hip was therefore explored and the sciatic nerve was found to be stretched over the front of the neck of the prosthesis (Fig. 1). We were unable to release the nerve without dislocating the hip so the trochanter was detached again and the hip dislocated. Once released, the nerve lay without tension; the hip was relocated and the trochanter reattached. Immediately 